\title{
From airports to airport territories: expansions, potentials, conflicts
}

\section{Yves Boquet*}

\author{
University of Burgundy, France
}

\begin{abstract}
Airports, as nodes in world transport networks, have been studied mostly in their role as hubs in the spatial strategies of airlines. This paper examines the role of airports as engines of growth in their local surroundings and the complexity of the spatial system of the airport at the local and regional scale. It studies how to ensure an efficient movement of planes of the airside and an efficient access point to airports on the landside while taking into account the interests of people living next to airports, who are heavily impacted the noise generated by aircraft, as well as considering where should new airports be built.
\end{abstract}

Key Words: airport, accessibility, congestion, local economy, NIMBY, noise.

Article Info: Received: August 10, 2018; Revised: September 8, 2018; Accepted: November 3, 2018; Online: November 30, 2018.

\section{Introduction}

Geography has been defined as "the science of territories and networks" (Brunet 1995). Airports can be considered as places located at the intersection of global networks and local territories. They are no longer just places where airplanes take off and land but have become significant businesses with spatial impacts and functional implications that extend into metropolitan areas (Freestone, 2009; Freestone and Baker, 2011). The role of infrastructure as a factor of growth and development of countries and regions is now recognized as crucial. Airports are considered as particularly strategic because of the increasing importance that air transport has in connecting territories (Bowen, 2013). At the interface between ground and sky, airports can be analysed both locally and

* Correspondence address

Address: Université de Bourgogne, 4 Boulevard Gabriel, 21000 Dijon, France

Phone: +33380395730| Email: yves.boquet@u-bourgogne.fr

(C)2018 Human Geographies; The authors

(c) (1) This work is licensed under a

Creative Commons Attribution 4.0 International License. DOI:10.5719/hgeo.2018.122.1 
globally as nodes in the global space of flows (Schaafsma, 2003), as functional anchor points of globalization (Frétigny, 2012), as tools of international competitiveness (hubs, gateways), as well as structuring elements of local territories and engines of metropolitan growth. As hubs of global flows, they are a part of the knowledge economy (Conventz et al., 2014).

Some now hold a key position in high-speed rail networks (Givoni, 2007), a role formerly reserved for central train stations only (Labasse, 1972). Airports used to confirm the success of a city; they are now a factor in its sustained success. For cities and metropolises, a high-performance airport is an essential factor of competitiveness (Union des Aéroports Français, 2017), a tool at the service of local and regional, economic and touristic development. Contrary to their being perceived as "non-places" (Augé, 1992), airports are also showcases of their country or regions, and they are often named after influential national figures, even if the vast majority of airports' names refer to the city or area they serve. In this article, the author favours the local scale to analyse the insertion of airports in their local territories and the interactions between an airport and an urban/metropolitan area (Varlet, 1997; Cidell and Adams, 2001; Berthon, 2003; Kesselring, 2010).

\section{The role of airports as engines of growth}

Airports can be considered as key components for the transformation of metropolitan areas. The economic impact of an airport plays out at different territorial scales. It is at the same time a local economic centre (representing tens of thousands of jobs) and a job attractor in its immediate proximity (freight handling areas, hotels, conference centres, and others). The presence of the airport itself and the excellent quality of the land transport infrastructures which serve it make it an engine of local and regional growth (Zaninetti, 2000; Hakfoort et al., 2001; Hujer, 2008; Cidell, 2015). It has an essential role as a real estate player (Reiss, 2007; Morrison, 2009).

Tourism also gains significantly from the presence of an airport, thanks to the increased accessibility provided by the air transport facility. All the benefits mentioned above reach their maximum effect in the case of islands (Gay, 2000; Karampela, Kizos and Spilanis, 2014). Airports are widely seen as fostering direct employment (airlines' ground staff and air crews, air traffic controllers, airport shops and services employees, security) and indirect employment (offices, logistics zones) jobs (Conventz, 2010; Percoco, 2010). Local governments worldwide are therefore agreeing that an airport has mostly positive effects on a region. However, there are disagreements about just how much additional employment and added value an airport generates. It differs between 200 en 2,000 extra jobs per million passengers. It has been estimated that a $10 \%$ increase in the volume of air traffic in a metropolitan area generates a $1 \%$ increase in employment in service activities (Brueckner, 2003) and that each airport job leads to the creation of another non-airport job (Berthon and Bringand, 2001). CDG-Roissy airport in Paris and Frankfurt Rhein-Main harbour some 85,000 jobs each, Amsterdam-Schiphol around 60,000, just on airport platforms, while the Greater Roissy area employs about 160,000 people. 
John Kasarda introduced and popularized the Aerotropolis model (Kasarda, 2006; Kasarda and Lindsay, 2011; Shen and Cao, 2016), which can be refined by distinguishing Berthon (2001) the airport city (Berthon and Bringand, 2001; Güller and Güller, 2002; Appold and Kasarda, 2013) at the very heart of the airport platform, from the airport and its wider environment. A rich array of terms have emerged: airport region (De Jong et al., 2008; Van Wijk, 2008), Airea (Schlaack, 2010), aerocity (Roseau, 2012), aviapolis in Helsinki, or aeroville (CREPIF, 1989; Ray, 1989; Piercy, 1999) and finally the airport corridor (Schaafsma, 2010) between the airport and the city, which is a prime location for the establishment of high-tech activities, as seen in Washington DC alongside the Dulles airport access road (Boquet, 1986, 1989).

According to Kasarda, the $21^{\text {st }}$ century will be dominated by air transport, and the airport will function as a city (Drevet-Demettre, 2015) in itself, with living spaces for workers and their families, with factories relying on airline logistics services located near the airport and served by major road and rail infrastructure. Activities within the airport space (aviation, land transportation, shopping facilities, cargo warehousing, hotels, offices) (McNeill, 2009) would provide increased added value (and additional tax revenues) to a larger area, the aerotropolis, by stimulating the development of industrial parks, logistics zones, shopping centers, leisure and tourism activities and conferences, which in turn will fuel the growth of air traffic.

The airport would be a magnet attracting economic activities (Hesse, 2014]). IKEA, for example, has set up one of its stores, right next to the runways of Athens airport in Greece (Kasarda, 2008). The Aerotropolis concept has been included in the general layout of large American cities such as Atlanta (Aerotropolis Atlanta Blueprint), Memphis around the Fedex hub (Cox, 2010), or in Detroit, as well as in Dubai (Alkaabi et al., 2013). It is being implemented in Paris, Amsterdam, Frankfurt and Moscow (Thorez, 2010) and has been the subject of symposia for several years in Singapore, which appears with Dubai as a model (Lohmann et al., 2009; Van Wijk, 2011) that other Asian cities want to follow (Yeo et al., 2013), despite the doubts of some authors about the sustainability of the aerotropolis model (related to energy supply and infrastructure safety for example) (Charles et al., 2007).

Airports are part of local territories through the construction of land-based modes of access (road, metropolitan rail, intercity rail, or even maritime access as in Hong Kong, Kobe and Osaka-Kansai), the quality of intermodalities, the environmental constraints they are submitted to (site requirements: long runways on flat terrain, unobstructed approach from the air) and the adverse effects they generate (noise pollution, air pollution), giving rise to local land use conflicts (see section 4). Access to the airport requires substantial investments that will benefit the entire airport area, while it is also an opportunity to shift away from automobile-based mobilities to alternative modes of land transportation. Empirical studies seem to show that individuals who are on business trips, flying alone (or with fewer people), and already trying to reduce their automobile use, in general, are more likely to take alternative modes of transportation to the airport (Akar, 2013). Taxis, bus shuttles and metro systems seem to be the growing forms of access to airports (Tam, Tam and Lam, 2005; Alhussein, 2011), the latter ones being the preferred option if the quality of service is good (no 
stairs, easy access from airside facility, secure connection to city transportation downtown), as analyzed by researchers in Hong Kong and Seoul (Tam, Lam and Lo, 2010; Chou, You and Lee, 2011).

\section{Reorganising airports for the growth of air traffic}

The increasing saturation of airports complicates this management of airport constraints (Roosens, 2008). The growth of traffic and number of flights with hub strategies on the one hand, which force airports to be able to accommodate at the same time a growing number of aircraft arriving in successive waves, the explosion of low-cost traffic on the other hand (Bowen, 2016), which opens small town airports (Bergerac, in southwestern France, for example) to international flights, have combined with the need to develop airports to receiving the largest aircraft (Boeing 747-400 and newer, Airbus A 380) (Berster et al., 2015) and the rise of air cargo hubs (Boquet, 2009) to increase the pressure for expanded airport facilities. Old runway configurations are nowadays inadequate: intersecting runways (Manila) or too close to each other, the insufficient number of runways: no large international airport can operate with a single track. This resulted in the closure from Hong Kong's Kai Tak airport. A new runway configuration means not only allowing more planes to land safely, but also providing them with wider tarmac parking spaces. As far as passengers go, some airport terminals are too small: the number of boarding gates may be too small to accommodate more passengers in tourism cities (Yogyakarta, Indonesia is a good example), hence some unpopular transfers to/from the terminal by buses if there is no boarding/disembarking directly from the air terminal, commercial spaces obsolete and too cramped as airports rely more and more on shopping areas to increase their revenues (Bork, 2006; Graham, 2009; Boquet, 2010). In cities, inadequate access roads to airports (traffic jams, lack of rail links) also lead to major works in the area surrounding airports (Navarre, 2003a).

Various strategies can be implemented to manage the increase in air traffic at an airport and to reduce increasing congestion that results in delays in flights: banning recreational aviation or private jets, capping the number of flights and/or passengers (Orly airport near Paris), optimizing scheduling of flights through a specialization of runways (one for takeoffs, one for landings) to maximize the efficiency of their use (Netjasov, 2008; Bennell, Mesgaspour and Potts, 2011), especially in hub airports such as Zürich-Kloten or Hong Kong Chek Lap Kok, reallocating flight slots with variable landing fees depending on the time of day (slot pricing and slot auction strategies) (Madas and Zografos, 2006; Condorelli, 2007; Brueckner, 2009; Basso and Zhang, 2010).

Through an increase in airport fees to finance constructions, one can also transform the airport in order to better respond to the increasing volume of activity and make the airport adaptable to change (Butters, 2010; Carlisle, 2015; Suh and Ryerson, 2017).

In the case of an existing airport, this may involve new, longer, better structured runways, sometimes requiring an expansion of the airport perimeter, which is difficult if the facility is located inside a dense urban fabric or if site constraints limit the size of the airport (Washington Reagan, which can not 
accommodate large aircraft). New runways were built recently at Amsterdam Schiphol, Berlin Brandenburg, Brisbane, Dublin, Frankfurt Rhein-Main, Rio de Janeiro Galeão, Shanghai Hongqiao, Tokyo Haneda, Washington Dulles. Projects for new runway are implemented or planned in Hong Kong Chek Lap Kok, London Gatwick, London Heathrow, Lyons St. Exupery, while Chicago O'Hare (Johnson and Savage, 2006; Cidell, 2013) has seen a complete redesign of its set of runways: the O'Hare Modernization Plan included the construction of four new runways, the lengthening of two existing runways, and the decommissioning of two older NW-SE runways in order to give the airport six parallel East-West runways and two crosswind NE-SW runways, all while managing to keep the airport, one of the busiest in the world, fully operational.

Airport terminals can be expanded, or new ones created (Abu Dhabi, Chicago O’Hare, Chongqing, Detroit, Moscow Domodedovo, Moscow Vnukovo, Munich (Ahrens and Stein, 2016), New Delhi, Paris CDG, Beijing Capital, Singapore Changi, Tokyo Narita, and others), resulting in a capacity increase with more boarding gates (although a large airport may not necessarily provide contact boarding/disembarking, as the case of Riyadh shows), a higher number of parking spaces for cars on the city side, and a sharp increase in commercial space in airport terminals, while taking into account security requirements and controlled passenger circulations within the airport facility (passengers in transit, traffic inside the European Schengen area, authorized or unauthorized migrants, and others) (Edwards, 2004; Iserte, 2008; Frétigny, 2013a,b; Goodpasture and Hubbell, 2016). In Saudi Arabia, Jeddah airport has built a Hajj terminal which is opened only at the time of the pilgrimage to Mecca. When addressing the building's form, functionality, efficiency, sustainability, and adaptability are critical to the design. The spiritual and medical needs of passengers must also be considered, as well as the need for multilingual ground personnel and international signage to help passengers in an unknown language environment (Fuller, 2002; Lam et al., 2003; Kellerman 2008).

Access to the airport can be facilitated by new road or rail services, which may be local via a subway line, such as in Bangkok, Hong Kong (Airport express) (Budge-Reid, 1999), Kansai, Kuala Lumpur, CDG-Roissy (RER B line), San Francisco (BART), Atlanta (MARTA), Chicago O'Hare, Shanghai Pudong by maglev service (Fu et al., 2017), Singapore (Phang, 2003) and longer distance by high-speed train (Navarre, 2003b), in CDG-Roissy, Amsterdam Schiphol, Brussels Zaventem, Düsseldorf, Frankfurt (Eichinger, 2007), Lyons or Shanghai Hongqiao (Chen and Lin, 2015). This rail service, now provided in 86 of the world's 100 largest airports, seems to be an increased factor in the competitiveness of metropolitan areas (Murakami et al., 2016).

\section{Building new airports}

Another strategy is to open a new airport, which could entirely replace the old one, whose space, often closer to the city center, is reassigned to new non-air uses, in a strategy of brownfields reclamation, as in Hong Kong (Kai Tak replaced by Chek Lap Kok, with the old site earmarked for a new residential district, a park and a cruise terminal) (Loo and Chow, 2011; Lau et al., 2014; 
McNeill, 2014) or Denver (closure of Stapleton Airport, now an eco-district following the concepts of New Urbanism and Smart Growth, replaced by Denver International) (Szyliowicz and Goetz, 1995; Goetz and Szyliowicz, 1997). Of course, there is some contradiction between developing a new airport out-oftown, which induces more sprawl and refocusing urban development to central areas to reduce sprawl (Godschalk, 2004; Goetz, 2013). The problem of reconverting abandoned airport sites also arose in the case of Athens Hellenikon, Austin Mueller, Berlin Tempelhof (Dubeaux and CunninghamSabot, 2016; Hilbrandt, 2017), El Toro Marine Air Station in California (Boquet, 2004a), Manila's Makati Nielson Field, Munich Riem, Oslo Fornebu.

Many large metropolises operate a two-airports system, as can be seen in Chicago (Midway, O’Hare), Houston (Hobby, G. Bush), Dallas (DFW, Love Field), Milan (Linate, Malpensa), Rome (Fiumicino, Ciampino), Berlin (Schönefeld, Tegel), Tokyo (Haneda, Narita), Shanghai (Hongqiao, Pudong), Jakarta (Soekarno-Hatta, Halim), Bangkok (Don Muang, Suvarnabhumi), Seoul (Kimpo, Incheon), Taipei (Taoyuan, Songshan), Rio de Janeiro (Galeão, Santos Dumont) or in the ongoing projects of Beijing and Dubai, possibly Atlanta in the near future. Some major metropolitan areas are operating under a multiple airport system, leading to interesting questions of competition and cooperation between airports, air traffic management, passengers' airport choice, and transfers between airports (De Neufville, 1995; Pels, Nijkamp and Rietveld, 2001, Martin and Voltes-Dorta, 2011; Perdana and Moxon, 2014; Yang, Yu and Notteboom, 2016, Pan and Truong, 2017). It is the case of New York City (JFK Airport, Newark, La Guardia, Teterboro, Long Island, Stewart), San Francisco (SFO, San Jose, Oakland), Los Angeles (LAX, Burbank, Ontario, Long Beach, Santa Ana), Washington (Dulles, Reagan National, BWI Baltimore-Washington Interna-tional), London (Heathrow, Gatwick, Stansted, Luton, London City), Paris (Roissy-CDG, Orly, Le Bourget, Beauvais-Tillé), Moscow (Sheremetyevo, Vnukovo, Domodedovo, Zhukovsky) and the Pearl River delta area of southern China (Hong Kong, Shenzhen, Guangzhou, Macau, Zhuhai).

The list of new airports built in the last twenty years is long: Athens Eleftherios Venizelos, Bangkok Suvarnabhumi, Denver International, Fort Worth Alliance Freight Airport (Boquet, 1998), Guangzhou New Baiyun, Guiyang, Hong Kong Chek Lap Kok, Kobe, Kuala Lumpur International, Nagoya Centrair, Osaka Kansai, Seoul Incheon, Shanghai Pudong, and ongoing projects (Atlanta 2, Chengdu, Dakar Blaise Diagne, Dalian, Doha Hamad, Dubai Al-Maktoum, Islamabad, Lisbon (Abreu e Silva et al., 2015), Manila, Mexico (Sanchez, 2017a), Beijing Daxing, Qingdao). China, with the very rapid development of its air transport (Boquet and Song, 2007; Zhang et al., 2010; Chen, Barros and $\mathrm{Yu}, 2017$ ), has been the most active country in the construction of new airports: thirteen new airports were built in the period 1986-1995 and another 37 existing airports were upgraded.

The Civil Aviation Administration of China (CAAC) then announced its intention to commence up to 100 upgrading projects and new airports. The construction of new airports brought the total number to 160 by 2005 and 206 in 2016. The Go West strategy continued to favour the building of new air facilities in the country (66 more airports currently being built): Guizhou province, for example, now boasts 11 commercial airports (while there were 
only 2 in 1997: Anshun - opened in 2002, Bijie - 2013, Guiyang - 1997, Kaili 2013, Libo - 2007, Liping - 2005, Liupanshui - 2014, Tongren - 2001, Xingyi 2004, Zunyi - 1970, Zunyi-Renhuai - 2017). Sometimes the new airport is the result of the reassignment of military bases to the civilian sector, such as Austin Bergstrom, Chateauroux-Deols, Columbus Rickenbacker, Frankfurt Hahn, Paris Vatry, Rome Viterbo, Angeles City Clark and Subic Bay in the Philippines. Many of them are freight airports or used by low-cost airlines.

Site constraints are important: a modern international airport must have a large land area, to allow for unobstructed air approaches, keep sufficient distances between runways, and significant spaces for aircraft parking. The airport footprint can, therefore, be considerable, as in Saudi Arabia: King Fahd Airport (Dammam) who occupies 78,000 hectares, seven times the size of the city of Paris. King Khalid Airport in Riyadh (22,500 ha), King Abdulaziz Airport in Jeddah (15,000 ha), Denver International (13,726 ha) and Kuala Lumpur International (10,000 ha) are also more extensive than the French capital, as is the new Dubai Al Maktoum Airport (14,000 ha) under construction. RoissyCharles de Gaulle is the largest in Europe (3,200 ha) ahead of Madrid Barajas. It is sometimes difficult to build an airport in very rugged terrain. Those of Guiyang, the capital city of the Chinese province of Guizhou, and Hechi (Guangxi) could only be built at the cost of levelling dozens of karstic peaks and the construction of an artificial plateau.

Proximity constraints are also essential elements to consider. The most desirable situation is maximum proximity of an airport to the city, if one considers the need to reach a large manpower pool (mechanics, building maintenance staff, security, shops, staff of the world aeronautics) and meet passengers' demand for a proximity airport reducing access time, such as in San Diego-Lindbergh, Salt Lake City, Boston-Logan or Washington-Reagan, whose airports are located just minutes from downtown.

In contrast, the higher distance of the airport from urbanised areas has the advantage of minimizing the number of people affected by noise and odours but is hugely inconvenient to recruit staff and is not appreciated by airlines, which understand the wishes of their passengers to avoid long land trips to and from the airport. It may, therefore, happen that a new airport in the middle of nowhere is a failure, because it is too far from the city it serves, and thus shunned by airlines listening to their passengers. Classic examples are Ciudad Real, Montreal Mirabel, St Louis Mid-America or Saõ Paulo Viracopos. WashingtonDulles, at its inception, was also considered a white elephant before an access highway connected it to the US capital Beltway ring road. Today a subway is under construction on the access road's central strip, scheduled to serve the airport in 2020. Only specialized freight activities, such as in Vatry, between Troyes and Châlons-en-Champagne, can develop there, unless a low-cost company chooses to sell the airport as Paris (Vatry), Frankfurt (Hahn), Brussels (Charleroi), despite being located tens of kilometers from the main city, with the need to design a correct ground service of the airport, which is far from being the case. In Europe, Ryanair is using this strategy to circumvent major hubs, but land access is difficult for passengers.

Japan has developed an original solution by building airports on man-made islands (Nijkamp and Yim, 2001), Osaka Bay (Kansai International and Kobe 
Airport) or Nagoya (Centrair Airport). Planes can operate 24/24 without obstacles or awakening the nearby population in the middle of the night. Such a project is currently considered in Manila Bay, Philippines. Several other airports are built mostly on reclaimed land just off the coastline, in Nice, Hong Kong, San Francisco or Seoul-Inchon. The Pointe-à-Pitre runway (Guadeloupe) extends in the middle of mangroves. Two significant difficulties here are the very high cost of construction (including rail and road links) and maintenance (against the risk of ground subsidence under the repeated weight of aircrafts) (Douglas and Lawson, 2003; Puzrin et al., 2010), which cause airports to impose high airport taxes on airlines, and create major disruptions to fragile coastal and marine environments.

\section{Contesting airports}

Airport-driven urban development, despite its capacity and potential employment and income generation, however, has costs and presents risks in different realms, economic, environmental, social and cultural. An airport close to the city causes noise pollution (despite the remarkable progress by aircraft and plane engines manufacturers in reducing the volume of aircraft noise), which is strongly opposed by residents) especially at night, and air (unpleasant kerosene odors) (Cohen et al., 2007). Except maybe for thrill seekers like tourists at Maho Beach, on the Caribbean island of Sant Maarten, standing behind the barrier of Princess Juliana airport, to enjoy the flying of jetliners a few meters above their heads in the final landing phase, or the blast of reactors at the time of take-off. This unique hobby killed a New Zealand tourist in July 2017.

Noise, as the strongest airport nuisance, impacts heavily and repeatedly large areas, either metropolitan (Dos Santos and Saad, 2014) or touristic spaces, such as France's Côte d'Azur (Spill and Spill, 1973). Some airports have set night-time curfews that constrain airline activity, particularly for freight carriers with maximum nighttime activity (Fedex Superhub in Memphis, UPS Worldport in Louisville) (Kasarda and Sullivan, 2006; Boquet, 2009). This led DHL to abandon its Brussels hub for Leipzig due to growing opposition to nighttime airport noise by Brussels citizens (Dobruszkes, 2008; Oosterlynck and Swyngedouw, 2010).

There is also concern about risks: even though air transport is now extremely safe, there are still accidents, which occur mostly in the delicate phases of take-off and landing, thus near airports. The value of real estate is affected by the frequency and intensity of aircraft noise (Tomkins et al., 1998; Espey and Lopez, 2000; Faburel and Maleyre, 2007; Mense and Kholodilin, 2014; Sedoarisoa et al., 2017) and the effects of noise on health (sleep disorders, hypertension, cardiovascular disorders) (Eriksson et al., 2007; Järup et al., 2008; Huss et al., 2010), as well as those of air pollution (asthma) are better known by medical researchers (Meister and Donatelle, 2000; Passchier et al., 2000; Rosenlund et al., 2001; Franssen, Staatsen and Lebret, 2002; Black et al., 2007; Faburel and Charre, 2008; Schreckenberg et al., 2010; Callejas et al., 2012; Ancona et al., 2014). The NORAH concept (Noise-Related Annoyance, Cognition, and Health) encapsulates these disagreements (Schreckenberg et al., 
2012). In developing countries, the immediate vicinity of airports is colonised by shanty towns, in a typical example of environmental injustice where the poor live in dangerous places and marked by many nuisances, as in India in Mumbai (Arputham and Patel, 2010) or Kolkata.

NIMBY-style opposition reactions to airport expansion or creation have developed, for example, at London Heathrow against a new runway (Hayden, 2014) and London Stansted (Griggs and Howarth, 2008), as it was also the case for a long time about the second runway of Tokyo Narita, the many delays incurred at the new Berlin Brandenburg Airport (Becké et al., 2011) or at the long fight of farmers and environmentalists against the planned Notre-Damedes-Landes airport site near Nantes, France. Here, after decades of planning, and prolonged conflict with environmental and anarchist groups, the French government decided in early 2018 to pull the plug on this project, while deciding to refocus on the development of the existing Nantes airport. An airport in rural areas may indeed be challenged by farming circles (RiallandJune, 2006) as obliterating good farming land or ruining a landscape forever. An example is the abandonment of the "3rd Paris Airport" project (Boquet, 2004b; Subra, 2004) envisioned either in Beauce or Picardie rich farmlands.

The development of an airport can no longer be exclusively centred on the needs of air transport (Kasioumi, 2015), but it must take into account the local environment, and local planning must take into account the requirements of air transport (Suau-Sanchez et al., 2011; De Barros, 2013; Scholl and Nebel, 2014). For example, zoning around Amsterdam Schiphol Airport (Van Wijk et al., 2011) allows only air transport-related activities (e.g. warehouses), and the airport's expansion (new runways) has moved away from the most populated areas, to minimise its impact on residential areas. Conversely, in Las Vegas, reducing the noise footprint of aircraft by using quieter engines has opened up new residential areas in the urban area (O'Reiley, 2013).

In many airports, as in London (Wolfe et al., 2017), Amsterdam, Paris, Boa Vista (Brazil) (Souza et al., 2017), GIS programs that offer noise modelling according to the planes trajectories, putting it in relation with the densities of population and the volume of recorded complaints, have made it possible to redefine approach and departure corridors. Pilots are requested to manoeuvre their aircraft in such a way as to limit noise over urbanised areas, especially during takeoff: they stabilise at low altitudes before resuming their climb over less populated areas, where engine thrust will be less troublesome (Girvin, 2009). In France, two regulatory documents, the Noise Exposure Plan (PEB, Plan d'Exposition au Bruit) and the Noise Awareness Plan (PGS, Plan de Gêne Sonore), represent a complementary approach for the reduction of aircraft noise conflicts.

The PEB (Noise Exposure Plan) is an urban planning document that delineates areas of potential noise nuisance from an airport. It defines urban planning rules at a regional, supra-municipal scale, that would supersede the various urban planning documents (SCOT, Schéma de Cohérence Territoriale, PLU, Plan Local d'Urbanisme, etc.) by prohibiting or limiting the possibilities of construction in areas subject to aircraft noise. These zones are defined from medium and long-term traffic hypotheses (15-20 years) as a function of the frequency, flight direction and known sound characteristics of a sample of 
different aircraft. It is divided into three time slots: daytime $6^{00}-18^{00}$, evening $18^{00}-22^{00}$, night $22^{00}-6^{00}$.

The PGS is a geographical document, exclusively dedicated to helping residents, which delimits urban areas adjacent to an airport. It delineates an area of "real" noise nuisance from an airport, based on forecasts of actual shortterm traffic ( 1 to 2 years) using the same calculation model as that used for the calculation of the PEB. The noise limit defines an area within which existing dwellings are eligible for financial assistance for sound insulation work. The PGS is revised every 2 to 3 years; according to the evolution of air traffic.

\section{Conclusion}

Airports, as nodes for worldwide air networks and local land transport networks, are also generators of two types of superposed territories. These are territories of economic activity and employment boosted by the presence of an airport, especially in the case of air freight airports or aircraft assembly sites (Toulouse, Hambourg, Everett, Renton), but also social territories where public dissatisfaction with the negative aspects of aviation can lead to anti-aircraft movements.

Opposition to airports is currently evolving towards a criticism of aviation itself, with issues such as climate change (Griggs and Howarth, 2013), degradation of coastal environments (offshore airports in Japan, Hong Kong, airports built on mangroves or coral reefs), or neo-liberal system of hypermobility as a corporate norm, inviting the consideration of airports as creators of an airport territory (Faburel, 2003a, 2010) defined by the area of mobilization against its negative impacts, and not just as nodes in a globalized airline network.

The continued growth of air transport in the years to come - despite the looming peak oil that may force a reduction of airline activities, jointly with growing preoccupations with global warming and climate change where aviation plays a role not yet fully assessed by atmosphere scientists (in February 2017, a planned expansion of Vienna airport - construction of a third runway - was temporarily blocked by Austrian justice under the novel ground of its future impact on climate (Hollaus, 2017)) - may lead to more local conflicts about the development of large facilities. Airports, usually seen as meeting places, engineering challenges, and economic assets have also become a political question pitting economy and ecology against each other and requiring a mediation of potential conflicts (Faburel, 2003b; Geis, 2010; O'Doherty, 2014; Sanchez, 2017b).

\section{References}

Abreu e Silva, J., Gonçalves, J., Correia, M.D.F. and Marreiros, S. (2015), "Airport Planning Process. The case of the new Lisbon Airport", Finisterra, vol. 50, no. 99, p. 63-79.

Ahrens, P. and Stein, M. (2016), "Munich Airport Terminal 2 Satellite: Airport expansion under ongoing operations", Journal of Airport Management, vol. 10, no. 2, p. 118-130. 
Akar, G. (2013), "Ground access to airports, case study: Port Columbus International Airport", Journal of Air Transport Management, vol. 30, p. 25-31.

Alhussein, S. (2011), "Analysis of ground access modes choice King Khaled International Airport, Riyadh, Saudi Arabia", Journal of Transport Geography, vol. 19, no. 6, p. 1361-1367.

Alkaabi, K, Debbage, K. and Bin Touq, A. (2013), "The Promise of the Aerotropolis Model in the United Arab Emirates: The Role of Spatial Proximity and Global Connectivity", The Arab World Geographer, vol. 16, no. 3, p. 289-312.

Ancona, C., Golini, M. Mataloni, F., Camerino, D., Chiusolo, M., Licitra, G., Ottino, M., Pisani, S., Cestari, L., Vigotti, M.A., Davoli, M. and Forastiere, F. (2014), "Valutazione dell'impatto del rumore aeroportuale sulla salute della popolazione residente nelle vicinanze di sei aeroporti italiani", Epidemiologia $e$ Prevenzione, vol. 38, no. 3-4, p. 227-236.

Appold, S. and Kasarda, J. (2013), "The Airport City Phenomenon: Evidence from Large US Airports", Urban Studies, vol. 50, no. 6, p. 1239-1259.

Arputham, J. and Patel, S. (2010), "Recent developments in plans for Dharavi and for the airport slums in Mumbai", Environment and Urbanization, vol. 2, no. 2, p. 501-504.

Augé, M. (1992), Non-lieux, Introduction à une anthropologie de la surmodernité, Seuil, Paris.

Basso, L. and Zhang, A. (2010), "Pricing vs. slot policies when airport profits matter", Transportation Research Part B: Methodological, vol. 44, no. 3, p. 381-391.

Becké, A.B., Hartmann, F., Hermann, C., Heyne, L., Hoeft, C., Kopp, J. and Marg, S. (2011), Die Proteste gegen den Flughafen Berlin Brandenburg (BER/BBI) Eine explorative Analyse der Protestteilnehmer, Göttinger Institut für Demokratieforschung, viewed 15 April 2018, https://goo.gl/owYUBq.

Bennell, J., Mesgarpour, M., and Potts, C. (2011), "Airport runway scheduling", 4OR, A Quarterly Journal of Operations Research, vol. 9, p. 115-138.

Berster, P., Gelhausen, M., and Wilken D. (2015), "Is increasing aircraft size common practice of airlines at congested airports?", Journal of Air Transport Management, vol. 46, p. 40-48.

Berthon, E. (2003), "De l'aérodrome à l'aéroport-ville: l'impact des aéroports sur leur territoire d'accueil", Cahiers de l'IAURIF, no.139-140, p. 72-81.

Berthon, E. (2011), "Les impacts territoriaux des aéroports. Présentation pour Paris-Métropole", viewed 5 April 2018, https://goo.gl/9KXxVT.

Berthon, E. and Bringand, F. (2001), L'Airport City et son intégration régionale, IAURIF, Paris.

Black, D., Black, J., Issarayangyun, T. and Samuels, S. (2007), "Aircraft noise exposure and resident's stress and hypertension: A public health perspective for airport environmental management", Journal of Air Transport Management, vol. 13, no. 5, p. 264-276.

Boquet, Y. (1986), "Les entreprises à technologie avancée dans la région de Washington DC", Bulletin de l'Association de Géographes Français, no. 3, p. 217 226.

Boquet, Y. (1989), "L'aéroport Dulles, pôle de croissance urbaine dans l'agglomération de Washington", Cahiers du CREPIF, symposium sur les aérovilles, 
Juin, no. 27, p. 129-139.

Boquet, Y. (1998), "Alliance Airport (Texas): logistique d'entreprises et développement métropolitain", Acta Geographica, no. 113, p. 39-50.

Boquet, Y. (2004a), "Enjeux métropolitains des nouveaux sites d'aéroports", in C. Siino, F. Laumière and F. Leriche (ed.), Métropolisation et grands équipements, Presses de l'Université du Mirail, Toulouse, p. 37-52.

Boquet, Y. (2004b), "Un aéroport international en Picardie ? Réflexions critiques sur un projet d'infrastructure de transport", in Y. Boquet, E. Désiré and J.M. Hoeblich (coord.), Territoires et Sociétés, Mélanges offerts au professeur Paul Oudart, Amiens, Association d'Etudes et de Cartographie Régionales de Picardie, Amiens, p. 95-106.

Boquet, Y. (2009), "Les grands aéroports de fret", Bulletin de l'Association de Géographes Français, vol. 86, no. 4, p. 472-484.

Boquet, Y. (2010), "Commerce et mobilité: les boutiques d'aéroport", in Y. Boquet and R.-P. Desse, Commerce et Mobilités, Éditions Universitaires de Dijon, p. 61-71.

Boquet, Y. and Song, W. (2007), "L'aviation civile en Chine : mutations et disparités régionales", Acta Geographica - La Géographie, Paris, no. 1523, 2006IV, p. 45-69.

Bork, A. (2006), "Developing a retail marketing strategy to promote both airport and retailers", Journal of Air Transport Management, vol. 1, no. 4, p. 348-356.

Bowen, J. (2013), The Economic Geography of Air Transportation: Space, Time, and the Freedom of the Sky, Routledge, London.

Bowen, J. (2016), "Now everyone can fly'? Scheduled airline services to secondary cities in Southeast Asia", Journal of Air Transport Management, vol. 53, p. 94-104.

Brueckner, J. (2003), "Airline Traffic and Urban Economic Development", Urban Studies, vol. 40, no. 8, p. 1455-1469.

Brueckner, J. (2009), "Price vs. quantity-based approaches to airport congestion management", Journal of Public Economics, vol. 93, no. 5-6, p. 681-690.

Brunet, R. (1995), "La géographie, science des territoires et des réseaux", Cahiers de Géographie du Québec, vol. 39, no. 108, p. 477-482.

Budge-Reid, A. (1999), "The Hong Kong Airport Railway", Japan Railway E Transport Review, no. 19, p. 36-43, viewed 2 April 2018, https://goo.gl/nmrVXL.

Butters, M. (2010), "Flexible airport design", Journal of Airport Management, vol. 4, no. 4, p. 321-328.

Callejas, L.M., Sarmiento, R., Medina, K., Sepulveda, H., Deluque, D. and Escobar-Córdoba, F. (2012), "Calidad del sueño en una población adulta expuesta al ruido del Aeropuerto El Dorado, Bogotá", Biomedica, vol. 35, p. 103-109, viewed 12 March 2018, https://goo.gl/DyHYy9.

Carlisle, A. (2015), "Airport business resilience: Plan for uncertainty and prepare for change", Journal of Airport Management, vol. 9, no. 2, p. 118-132.

Charles, M.B, Barnes, P., Ryan, N. and Clayton, J. (2007), "Airport futures: Towards a critique of the aerotropolis model", Futures, vol. 39, no. 9, p. 10091028.

Chen, Z. Barros, C. and Yu, Y. (2017), "Spatial distribution characteristic of Chinese airports: A spatial cost function approach", Journal of Air Transport Management, vol. 59, p. 63-70. 
Chen, X. and Lin, L. (2015), "The node-place analysis on the "hubtropolis" urban form: The case of Shanghai Hongqiao air-rail hub", Habitat International, vol. 49, p. 445-453.

Chou, S., You, S. and Lee, H. (2011), "Exploring characteristics of airport access mode choice: a case study of Korea", Transportation Planning and Technology, vol. 36 , no. 4 , p. 335-351.

Cidell, J. (2013), "When runways move but people don't: The O'Hare Modernization Program and the relative immobilities of air travel", Mobilities, vol. 8 , no. 4, p. 528-541.

Cidell, J. (2015), "The role of major infrastructure in subregional economic development: an empirical study of airports and cities", Journal of Economic Geography, vol. 15, no. 6, p. 1125-1144.

Cidell, J. and Adams, J. (2001), The Groundside Effects of Air Transportation, Minneapolis, University of Minnesota's Center for Transportation Studies, viewed 12 April 2018, https://goo.gl/LfXqKX.

Cohen, B., Bronzaft, A., Heikkinen, M., Goodman, J. and Nadas, A. (2007), "Airport-Related Air Pollution and Noise", Journal of Occupational and Environmental Hygiene, vol. 5, no. 2, p. 119-129.

Condorelli, D. (2007), "Efficient and equitable airport slot allocation", Rivista di Politica Economica, viewed 13 April 2018, https://goo.gl/Kaop93.

Conventz, S. (2010), "New office space at international hub airports. Evolving urban patterns at Amsterdam and Frankfurt/M.", in U. Knippenberger and A. Wall (eds.), Airports Cities and Regions. Research and Practise, KIT Scientific Publishing, Karlsruhe, p. 57-68.

Conventz, S. , Derudder, B., Thierstein, A. and Witlox, F. (2014), Hub Cities in the Knowledge Economy. Seaports, Airports, Routledge, Brainports.

Cox, L. (2010), "Evolving the Memphis Aerotropolis", Journal of Airport Management, vol. 4, no. 2, p. 149-55.

CREPIF (1989), Les aérovilles : nouveau concept d'intercommunication et de localisation d'entreprises, Les Cahiers du CREPIF, no. 27, Juin, Paris.

De Barros, A. (2013), "Sustainable integration of airports into urban planning a review", International Journal of Urban Sciences, vol. 17, no. 2, p. 226-238.

De Jong, B., Suau-Sanchez, P. and Dross, M. (2008), "The underestimated Airport Region: Reflecting on Planning Policies in the Airport Regions of Amsterdam, Barcelona and Munich", Aerlines, no. 41, p. 1-5.

De Neufville, R. (1995), "Management of multi-airport system. A development strategy", Journal of Air Transport Management, vol. 2, no. 2, p. 99-110.

Dobruszkes, F. (2008), "Éléments pour une géographie sociale de la contestation des nuisances aériennes à Bruxelles", Espace Populations Sociétés, no. 2008-1, p. 145-157, viewed 12 April 2018, https://goo.gl/9kVzUb.

Dos Santos, D.N. and Saad, A.R. (2014), "Análise do ruído sonoro no entorno de grandes aeroportos: Um estudo de caso do Aeroporto Internacional de São Paulo", Boletim Gaúcho de Geografia, vol. 42, no. 1, p. 337-351.

Douglas, I. and Lawson, N. (2003), "Airport construction: materials use and geomorphic change", Journal of Airport Management, vol. 9, no. 3, p. 177-185.

Drevet-Demettre, L.E. (2015), "Quand l'aéroport devient ville: géographie d'une infrastructure paradoxale", thèse de doctorat, Université Michel de Montaigne Bordeaux III, viewed 16 April 2017, https://goo.gl/Lcm1nj. 
Dubeaux, S. and Cunningham-Sabot, E. (2016), "Contestation et normalisation des usages du sol dans Berlin: l'ancien aéroport de Tempelhof", Natures, Sciences, Sociétés, vol. 24, no. 4.

Edwards, B. (2004), The Modern Airport Terminal. New Approaches to Airport Architecture, Taylor \& Francis, London.

Eichinger, A. (2007), "Characteristics and competitive implications of air-rail links in Germany", World Review of Intermodal Transportation Research, vol. 1, no. 3, p. 264-285.

Eriksson, C, Rosenlund, M, Pershagen, G, Hilding, A, Ostenson, C. and Bluhm, G. (2007), "Aircraft noise and incidence of hypertension", Epidemiology, vol. 18, no. 6, p. 716-721.

Espey, M. and Lopez, H. (2000), "The Impact of Airport Noise and Proximity on Residential Property Value", Growth and Change, vol. 31, no. 3, p. 408-419.

Faburel, G. (2003a), "Le bruit des avions. Facteur de révélation et de construction des territoires", L'Espace Géographique, vol. 32, no. 3, p. 205-223.

Faburel, G. (2003b), "Lorsque les territoires locaux entrent dans l'arène publique: retours d'expérience en matière de conflits aéroportuaires", Espaces et Sociétés, no. 115, p. 123-146.

Faburel, G. (2010), "Vers une (re)territorialisation des aéroports par les enjeux environnementaux. Conflits d'acteurs, enjeux de valeurs et recherche d'indicateurs", Bulletin de l'Association de Géographes Français, vol. 87, no. 2, p. 274-286.

Faburel, G. and Charre, S. (2008), Impacts des trafics aériens sur la santé. État des connaissances scientifiques et recommandations pour l'action, Créteil, Institut d'Urbanisme de Paris, viewed 20 April 2017, https://goo.gl/jy2oXa.

Faburel, G. and Maleyre, I. (2007), "Le bruit des avions comme facteur de dépréciations immobilières, de polarisation sociale et d'inégalités environnementales. Le cas d'Orly", Développement Durable et Territoires, Dossier 9, viewed 20 April 2017, https://goo.gl/Q6EKf5.

Franssen, E., Staatsen, B. and Lebret, E. (2002), "Assessing health consequences in an environmental impact assessment: The case of Amsterdam Airport Schiphol", Environmental Impact Assessment Review, vol. 22, no. 6, p. 633-653.

Freestone, R. (2009), "Planning, Sustainability and Airport-Led Urban Development", International Planning Studies, vol. 14, no. 2, p. 161-176.

Freestone, R. and Baker, D. (2011), "Spatial Planning Models of Airport-Driven Urban Development", Journal of Planning Literature, vol. 26, no. 3, p. 263-279.

Frétigny, J.-B. (2012), "Aéroport: non-lieu ou point d'ancrage du Monde ?", in C. Ghorra-Gobin (éd.), Dictionnaire critique de la mondialisation, p. 30-35, Armand Colin, Paris.

Frétigny, J.-B. (2013a), "Les mobilités à l'épreuve des aéroports: des espaces publics aux territorialités en réseau. Les cas de Paris Roissy-Charles-DeGaulle, Amsterdam Schiphol, Francfort-sur-le-Main et Dubai International", Ph.D thesis, Université Paris I-Panthéon-Sorbonne, viewed 20 April 20178, https://goo.gl/oAZQaR.

Frétigny, J.-B. (2013b), "La frontière à l'épreuve des mobilités aériennes: étude de l'aéroport de Paris Charles-de-Gaulle", Annales de Géographie, no. 690, p. 151-174

Fu, J., Lin, H., Niu, Y. and He, S. (2017), "Share Ratio Change of Public 
Transport in Airport Landside under the Background of Car Population Rapid Increase - A Case of Shanghai Pudong International Airport", Transportation Research Procedia, 25C, p. 92-102.

Fuller, G. (2002), "The Arrow-Directional Semiotics: Wayfinding in Transit", Social Semiotics, vol. 12, no. 3, p. 231-244.

Gay, J.-C. (2000), "La mise en tourisme des îles intertropicales", Mappemonde, no. 58 , p. 7-22.

Geis, A. (2010), "Beteiligungsverfahren zwischen Politikberatung und Konfliktregelung: Die Frankfurter Flughafen-Mediation", in P. Feindt and T. Saretzki (eds.), Umwelt-und Technikkonflikte, Wiesbaden, VS Verlag für Sozialwissenschaften, p. 259-274.

Girvin, R. (2009), "Aircraft noise-abatement and mitigation strategies", Journal of Air Transport Management, vol. 15, no. 1, p. 14-22.

Givoni, M. (2007), "Air-rail intermodality from airlines' perspective", World Review of Intermodal Transportation Research, vol. 1, no. 3, p. 224-238.

Godschalk, D. (2004), "Land Use Planning Challenges: Coping with Conflicts in Visions of Sustainable Development and Livable Communities", Journal of the American Planning Association, vol. 70, no. 1, p. 5-13.

Goetz, A. (2013), "Suburban Sprawl or Urban Centres: Tensions and Contradictions of Smart Growth Approaches in Denver, Colorado", Urban Studies, vol. 50, no. 11, p. 2178-2195.

Goetz, A. and Szyliowicz, J. (1997), "Revisiting transportation planning and decision making theory: The case of Denver International Airport", Transportation Research Part A: Policy and Practice, vol. 31, no. 4, p. 263-280.

Goodpasture, A. and Hubbell, S. (2016), "The evolution of the passenger experience on the airport concourse", Journal of Airport Management, vol. 10, no. 3, p. 283-290.

Graham, A. (2009), "How important are commercial revenues to today's airports?", Journal of Air Transport Management, vol. 15, no. 3, p. 106-111.

Griggs, S. and Howarth, D. (2008), "Populism, Localism and Environmental Politics: the Logic and Rhetoric of the Stop Stansted Expansion campaign", Planning Theory, vol. 7, no. 2, p. 123-144.

Griggs, S. and Howarth, D. (2013), The Politics of Airport Expansion in the United Kingdom: Hegemony, Policy and the Rhetoric of 'Sustainable Aviation', University of Manchester Press, Manchester.

Güller, M. and Güller, M. (2002), From airport to airport city, Barcelone, Gustavo Gili.

Hakfoort, J., Poot, T. and Rietveld, P. (2001), "The Regional Economic Impact of an Airport: The Case of Amsterdam Schiphol Airport", Regional Studies, vol. 35, no. 7, p. 595-604.

Hayden, A. (2014), "Stopping Heathrow Airport Expansion (For Now): Lessons from a Victory for the Politics of Sufficiency", Journal of Environmental Policy and Planning, vol. 16, no. 4, p. 539-558.

Hesse, M. (2014), "International hubs as a factor of local development: evidence from Luxembourg City, Luxembourg, and Leipzig, Germany", Urban Research and Practice, vol. 7, no. 3, p. 337-353.

Hilbrandt, H. (2017), "Insurgent participation: consensus and contestation in planning the redevelopment of Berlin-Tempelhof airport", Urban Geography, 
vol. 38 , no. 4 , p. 537-556.

Hollaus, B. (2017), "Austrian Constitutional Court: Considering Climate Change as a Public Interest is Arbitrary - Refusal of Third Runway Permit Annulled", Vienna Journal on International Constitutional Law (ICL Journal), vol. 11, no. 3, p. $467-477$.

Hujer, J. (2008), Regionalökonomische Effekte von Flughäfen, Peter Lang GMBH, Frankfurt-am-Main.

Huss, A., Spoerri, A., Egger, M. and Röösli, M. (2010), "Aircraft noise, air pollution, and mortality from myocardial infarction", Epidemiology, vol. 21, no. 6 , p. 829-836.

Iserte, M. (2008), "Enquête en 'zone d'attente réservée' de l'aéroport de ParisCharles de Gaulle: vers une gestion sécuritaire des 'flux migratoires', Cultures E Conflits, no. 71, p. 31-53.

Järup, L., Babisch, W., Houthuijs, D., Pershagen, G., Katsouyanni, K., Cadum, E., Dudley, M.-L., Savigny, P., Seiffert, I., Swart, W., Breugelmans, O., Bluhm, G., Selander, J., Haralabidis, A., Dimakopoulou, K., Sourtzi, P., Velonakis, M. and Vigna-Taglianti, F. (2008), "Hypertension and exposure to noise near airports: the HYENA study", Environmental Health Perspectives, vol. 116, no. 3, p. 329-333.

Johnson, T. and Savage, I. (2006), "Departure delays, the pricing of congestion, and expansion proposals at Chicago O'Hare Airport", Journal of Air Transport Management, vol. 12, no. 4, p. 182-190.

Karampela, S., Kizos, T. and Spilanis, I. (2014), "Accessibility of islands: towards a new geography based on transportation modes and choices", Island Studies Journal, vol. 9, no. 2, p. 293-306.

Kasarda, J. (2000), "Aerotropolis: Airport-Driven Urban Development", in ULI on the Future: Cities in the 21th Century, Urban Land Institute, Washington D.C..

Kasarda, J. (2006), Airport cities and the Aerotropolis, viewed 3 April 2017, https://goo.gl/LQhBJF.

Kasarda, J. (2008), "Shopping In the Airport City and Aerotropolis. New Retail Destinations in the Aviation Century", Research Review, vol. 15, no. 2, p. 50-55, viewed 13 April 2018, https://goo.gl/7dqiCm.

Kasarda, J. and Lindsay, G. (2011), Aerotropolis. The way we'll live next, Farrar, Strauss and Giroux, New York.

Kasarda, J. and Sullivan, D. (2006), "Air Cargo, Liberalization, and Economic Development", Annals of Air and Space Law, vol. 31, p. 167-93.

Kasioumi, E. (2015), "Emerging planning approaches in airport areas: the case of Paris-Charles de Gaulle (CDG)", Regional Studies, Regional Science, vol. 2, no. 1, p. 408-414.

Kellerman, A. (2008), "International Airports: Passengers in an Environment of 'Authorities'", Mobilities, vol. 3, no. 1, p. 161-178.

Kesselring, S. (2010), "Global transfer points. International airports and the future of cities and regions", in U. Knippenberger and A. Wall (eds.), Airports in Cities and Regions. Research and Practise, KIT Scientific Publishing, Karlsruhe.

Labasse, J. (1972), "L'aéroport et la géographie volontaire des villes", Annales de Géographie, no. 445, p. 278-297.

Lam, W.H.K., Tam, M-L., Song, S.C., and Wirasinghe, S.C. (2003), "Wayfinding in the passenger terminal of Hong Kong International Airport", Journal of Air 
Transport Management, vol. 9, no. 2, p. 73-81.

Lau, Y.Y., Tam, K.C., Ng, A.K.Y and Pallis, A.A. (2014), "Cruise terminals site selection process: An institutional analysis of the Kai Tak Cruise Terminal in Hong Kong", Research in Transportation Business E Management, vol. 13, p. 16-23

Lohmann, G., Albers, S., Koch, B. and Pavlovich, K. (2009), "From hub to tourist destination - An explorative study of Singapore and Dubai's aviationbased transformation", Journal of Air Transport Management, vol. 15, no. 5, p. 205-211.

Loo, B. and Chow, A. (2011), "Spatial Restructuring to Facilitate Shorter Commuting. An Example of the Relocation of Hong Kong International Airport", Urban Studies, vol. 48, no. 8, p. 1681-1694.

Madas, M. and Zografos, K. (2006), "Airport slot allocation: From instruments to strategies", Journal of Air Transport Management, vol. 12, no. 2, p. 53-62.

Martìn, J.C. and Voltes-Dorta, A. (2011), "The dilemma between capacity expansions and multi-airport systems: Empirical evidence from the industry's cost function", Transportation Research, vol. 47, no. 3, p. 382-389.

McNeill, D. (2009), "The airport hotel as business space", Geografiska Annaler: series B, Human Geography, vol. 91, no. 3, p. 219-228.

McNeill, D. (2014), "Airports and territorial restructuring: The case of Hong Kong", Urban Studies, vol. 51, no. 14, p. 2996-3010.

Meister, E. and Donatelle, R. (2000), "The impact of commercial-aircraft noise on human health: a neighborhood study in metropolitan Minnesota", Journal of Environmental Health, vol. 63, no. 4, p. 9-15.

Mense, A. and Kholodilin, K. (2014), "Noise expectations and house prices: the reaction of property prices to an airport expansion", The Annals of Regional Science, vol. 52, no. 3, p. 763-797.

Morrison, W. (2009), "Real estate, factory outlets and bricks: A note on nonaeronautical activities at commercial airports", Journal of Air Transport Management, vol. 15, no. 3, p. 112-115.

Murakami, J., MAtsui, Y. and Kato, H. (2016), "Airport rail links and economic productivity: Evidence from 82 cities with the world's 100 busiest airports", Transport Policy, vol. 52, p. 89-99.

Navarre, D. (2003a), "L'accessibilité terrestre aux aéroports", Cahiers de l'IAURIF, no. 139-140, p. 114-121.

Navarre, D. (2003b), "L'Europe de la grande vitesse et l'intermodalité passagers air-rail", Cahiers de l'IAURIF, no.139-140, p. 130-134.

Netjasov, F. (2008), "A Model of Air Traffic Assignment as a Measure for Mitigating Noise at Airports: The Zurich Airport Case", Transportation Planning and Technology, vol. 31, no. 5, p. 487-508.

Nijkamp, P. and Yim, H. (2001), "Critical success factors for offshore airports - a comparative evaluation", Journal of Air Transport Management, vol. 7, no. 3, p. 181-188.

O'Doherty, D. (2015), "Missing Connexions: The politics of airport expansion in the United Kingdom", Organization, vol. 22, no. 3, p. 418-431.

Oosterlynck, S. and Swyngedouw, E. (2010), "Noise Reduction: The Postpolitical Quandary of Night Flights at Brussels Airport", Environment E Planning A: Economy and Space, vol. 42, no. 7, p. 1577-1594.

O'Reiley, T. (2013), "Shrinking noise from planes will open up more acreage for 
development", Las Vegas Review Journal, January 21.

Pan, J.Y. and Truong, D. (2017), "Factors Influencing Passenger Choice in a Multiple Airport System", International Journal of Aviation Systems, Operations and Training (IJASOT), vol. 4, no. 1, p. 1-14.

Passchier, W., Knottnerus, A., Albering, H. and Walda, I. (2000), "Public health impact of large airports", Reviews on Environmental Health, vol. 15, no. 1-2, p. 83-96.

Pels, E., Nijkamp, P. and Rietveld, P. (2001), "Airport and airline choice in a multiple airport region: an empirical analysis for the San Francisco Bay Area", Regional Studies, vol. 35, no. 1, p. 1-9.

Peneda, M., Reis, V. and Macario, M. (2006), "Critical Factors for Development of Airport Cities", Transportation Research Record, vol. 2214, p. 1-9.

Percoco, M. (2010), "Airport Activity and Local Development: Evidence from Italy", Urban Studies, vol. 47, no. 11, p. 2427-2443.

Perdana, F.A. and Moxon, R. (2014), "Traffic distribution study on multi-airport sustems in the Greater Jakarta Metropolitan Area (GJMA) and associated implications", Civil Engineering Forum, vol. 23, no. 1, p. 1483-1487.

Phang, S.Y. (2003), "Strategic development of airport and rail infrastructure: the case of Singapore", Transport Policy, vol. 10, no. 1, p. 27-33.

Piercy, P. (1999), "Acteurs globaux et espaces locaux. Federal Express à Roissyen-France", L'Information Géographique, vol. 63, no. 4, p. 180-183.

Puzrin, A., Alonso, E. and Pinyol, N. (2010), "Unexpected Excessive Settlements: Kansai International Airport, Japan", in A. Puzrin, E. Alonso and N. Pinyol (eds.), Geomechanics of Failure, p. 23-43, Springer Science, Berlin.

Ray, P. (1989), "Territoires et urbanisme. Roissy, de l'aéroport à l'aéroville", Urbanisme, no. 230, p. 40-59.

Reiss, B. (2007), "Maximising non-aviation revenue for airports: Developing airport cities to optimise real estate and capitalise on land development opportunities", Journal of Airport Management, vol. 1, no. 3, p. 284-293.

Rialland-Juin, C. (2016), "Le conflit de Notre-Dame-des-Landes: les terres agricoles, entre réalités agraires et utopies foncières", Norois, no. 238-239, p. 133-145.

Roosens, P. (2008), "Congestion and Air Transport: a challenging phenomenon", European Journal of Transport and Infrastructure Research, vol. 8, no. 2, p. 137-146

Roseau, N. (2012), Aerocity : quand l'avion fait la ville, Parenthèses, Marseille.

Rosenlund, M., Berglind, N., Pershagen, G., Järup, L. and Bluhm, G. (2001), "Increased prevalence of hypertension in a population exposed to aircraft noise", Occupational and Environmental Medicine, vol. 58, no. 12, p. 769-773.

Sanchez, E. (2017a), "Lo urbano y lo local del nuevo aeropuerto internacional de la ciudad de México, en Texcoco, estado de México", Cuaderno Venezolano de Sociología, vol. 26, no. 3, p. 91-118.

Sanchez, E. (2017b), "Lo ambiental del Nuevo Aeropuerto Internacional de la Ciudad de México, en Texcoco, Estado de México", Letras Verdes, no. 22, p. 248-273, viewed 15 May 2017, https://goo.gl/9pnzVh.

Schaafsma, M. (2012), "Airports and Cities in Networks", diSP, The Planning Review, vol. 39, no. 154, p. 28-36.

Schaafsma, M. (2010), Airport and City - Airport Corridors: Drivers of Economic Development, Schiphol Real Estate, Amsterdam. 
Schlaack, J. (2010), "Defining the Airea. Evaluating urban output and forms of interaction between airport and region", in U. Knippenberger and A. Wall (eds.), Airports in Cities and Regions. Research and Practise, KIT Scientific Publishing, Karlsruhe.

Scholl, B. and Nebel, R. (2014), "Urban Transformation in Airport Regions", disP, The Planning Review, vol. 50, no. 2, p. 65-75.

Schreckenberg, D., Meis, M., Kahl, C., Peschel, C. and Eikmann, T. (2010), "Aircraft noise and quality of life around Frankfurt Airport", International Journal of Environmental Research and Public Health, vol. 7, no. 9, p. 3382-3405, viewed 10 May 2017, https://goo.gl/kRup8Z.

Schreckenberg, D., Eikmann, T., Guski, R., Klatte, M., Müller, U., Peschel, K., Schmidt, J., Seidler, A. and Möhler, U. (2012), "NORAH (Noise-Related Annoyance, Cognition, and Health) - Konzept einer Studie zur Wirkung von Verkehrslärm bei Anwohnern von Flughäfen", Lärmbekämpfung, vol. 6, no. 3, p. 107-114, viewed 9 May 2017, https://goo.gl/2z24gu.

Sedoarisoa, N., Desponds, D., Dalmas, L. and Lavandier, C. (2017), "Prix de l'immobilier et proximité de la plate-forme aéroportuaire de Paris - Charlesde-Gaulle (CDG)", L'Espace Géographique, vol. 46, no. 1, p. 61-78.

Shen, D. and Cao, Y. (2016), "Aerotropolis formation and evolution: insights from new economic geography", International Journal of Sustainable Development, vol. 19, no. 3, p. 246-256.

Souza, L., Reis Do Nascimento, C. and Coelho, A. (2017), "Elaboração de curvas de ruído para análise de uso e ocupaçao do solo no entorno do Aeroporto Internacional de Boa Vista - Atlas Brasil Cantanhede", Revista dos Transportes Públicos, vol. 40, no. 3, p. 113-124.

Spill, C. and Spill, J.M. (1973), "L'insertion de l'aéroport en milieu urbanisé. L'exemple de Marseille-Marignane et de Nice-Côte d'Azur", Méditerranée, vol. 15, no. 4, p. 49-72.

Suau-Sanchez, P., Pallares-Barbera, M. and Paül, V. (2011), "Incorporating annoyance in airport environmental policy: noise, societal response and community participation", Journal of Transport Geography, vol. 19, no. 2, p. 275284.

SubrA, P. (2004), "Roissy et le troisième aéroport: réalités économiques et manipulation géopolitique", Hérodote, no. 114, p. 122-180.

Suh, D. and Ryerson, M. (2017), "Frameworks for adaptive airport planning and techniques for a new era of planning", Transportation Research Record: Journal of the Transportation Research Board, vol. 2603, p. 65-77.

Szyliowicz, J. and Goetz, A. (1995), "Getting realistic about megaproject planning: The case of the new Denver International Airport", Policy Sciences, vol. 28, no. 4, p. 347-367.

Tam, M.L., Lam, W. and Lo, H.P. (2005), "Incorporating passenger perceived service quality in airport ground access mode choice model", Transportmetrica, vol. 6 , no. 1, p. 3-17.

Tam, M.L., Tam, M.L. and Lam, W. (2005), "Analysis of airport access mode choice: a case study in Hong Kong", Journal of the Eastern Asia Society for Transportation Studies, no. 6, p. 708-723, viewed 7 May 2017, https://goo.gl/hBJYEg.

Thorez, P. (2010), "Aéroports, ville et espace urbain: le cas de Moscou", Belgeo, 
no. 2010-1/2, p. 109-118, viewed 20 April 2017, https://goo.gl/NqDrkw.

Tomkins, J., Topham, N., Twomey, J. and Ward, R. (1998), "Noise versus Access:

The Impact of an Airport in an Urban Property Market", Urban Studies, vol. 35, no. 2, p. 243-258.

Union des Aéroports Français (2017), Les aéroports au service de l'attractivité des territoires. Le manifeste des aéroports français, Paris, viewed 21 April 2017, https://goo.gl/ZYM5s2.

Van Wijk, M. (2008), "Development of Airport Regions: Varieties of Institutions in Schiphol and Frankfurt", Aerlines, no. 40, p. 1-5.

Van Wijk, M. (2011), "Airport City models: Copy and Paste? Conditions for success and failure of interregional learning", Proceedings of The 9th International Conference of Eastern Asia Society for Transportation Studies, viewed 19 April 2017, https://goo.gl/ZnWw1m.

Van Wijk, M., Brattinga, K. and Bontje, M. (2011), "Exploit or Protect Airport Regions from Urbanization? Assessment of Land-use Restrictions in Amsterdam-Schiphol", European Planning Studies, vol. 19, no. 2, p. 261-277.

Varlet, J. (1997), "Les grands aéroports internationaux français (Roissy, Orly, Satolas, Nice): enjeux et retombées territoriales", Annales de Géographie, no. 593-594, p.155-182.

Wolfe, P., Kramer, J. and Barrett, S. (2017), "Current and future noise impacts of the UK hub airport", Journal of Air Transport Management, vol. 58, p. 91-99.

Yang, Z., Yu, S. and Notteboom, T. (2016), "Airport location in Multiple Airport Regions (MARs): the role of lad and airside accessibility", Journal of Transport Geography, vol. 52, p. 98-110.

Yeo, G.T., Wang, Y. and Chou, C.C. (2013), "Evaluating the competitiveness of the aerotropolises in East Asia", Journal of Air Transport Management, vol. 32, p. 24-31.

Zaninetti, J.-M. (2000), "Roissy et Cergy, pôles structurants au nord de l'Ile-deFrance: l'emploi salarié et les déplacements domicile-travail", Annales de Géographie, no. 612, p. 98-211.

Zhang, J., Cao, X.B., Du, W.B. and CaiI, K.Q. (2010), "Evolution of Chinese airport network", Physica A: Statistical Mechanics and its Applications, vol. 389, no. 18, p. 3922-3931. 